\title{
REVIEW OF THE SOCIAL SITUATION OF PARAPLEGIC AND TETRAPLEGIC PATIENTS REHABILITATED IN THE HEXHAM REGIONAL SPINAL INJURY UNIT IN THE NORTH OF ENGLAND OVER THE PAST FOUR YEARS
}

\author{
By R. A. Sutton, ${ }^{1}$ F.R.C.S.Ed., M. Bentley, ${ }^{2}$ M.A., A.I.M.S.W., B. Castree, ${ }^{3}$ \\ B.Med.Sci., R. Mattinson, ${ }^{4}$ S.R.N., J. Pattinson, ${ }^{5}$ C.Q.S.W. and R. SMith, F.R.O.T. ${ }^{6}$ \\ ${ }^{1}$ Consultant Orthopaedic Surgeon; ${ }^{2}$ Research Medical Social Worker; ${ }^{3}$ Medical Student, \\ Newcastle University; ${ }^{4}$ Charge Nurse; ${ }^{5}$ Senior Medical Social Worker; ${ }^{6}$ Head Occupational \\ Therapist: Hexham Regional Spinal Injury Unit, England
}

\begin{abstract}
The social circumstances of newly admitted patients rehabilitated in the North of England Spinal Injury Unit between 1975 and 1979 have been investigated. The following elements of their social circumstances have been briefly reviewed in this paper: housing and facilities in the house, mobility, health, pressure sore development, family relationships, sexual relationships, employment, compensation, and social integration. The resulting information enabled us to appropriately modify our rehabilitation progress as discussed.
\end{abstract}

Key words: Traumatic paraplegic and tetraplegic patients; Social circumstances; Rehabilitation; Modification of social services.

\section{Introduction}

THE circumstances of paraplegic and tetraplegic patients who have been rehabilitated in Spinal Injury Units, and who have been subsequently discharged home, have been investigated by several workers. Frequently, information relating to specific aspects of daily life has been reported (Jackson, 1972; Wilcox et al., 1972; Forner Jr et al., 1976) or the use of particular equipment at home has been reviewed (e.g. Spieker et al., I97I who reviewed upper extremity bracing). The problems of social integration have been studied with emphasis on particular aspects such as employment, services available (Hallin, 1968; Johnson et al., 1972) and degree of independence achieved (Runge, 1966).

We believe, however, that an assessment of these patients at their home on a considerably wider basis would provide a clearer picture of the overall quality of their lives. We would then be in a position to assess the overall value of our rehabilitation programme. We would consequently be in a position to modify appropriately our programme as required in order to provide a further improved service to our patients.

Our present programme of management has extended essentially from 1975. We have therefore examined the social situation of all new patients treated and rehabilitated in our Spinal Injury Unit between 1975 and 1979. This has allowed a minimum follow-up of I year since discharge.

\section{Method}

The survey was conducted using a semi-structured interview schedule administered by the same individual (Research Social Worker) throughout (M.B.). 
Computerised analysis of the results was carried out. Ninety-two patients were eligible to take part in our survey. Fifteen patients were not available for interview.

Of the available patients, only two declined to take part in the investigation, a satisfactory high compliance rate.

\section{Results and Discussion}

The age and sex distribution of the 75 patients taking part are noted in the legend to Figure I.

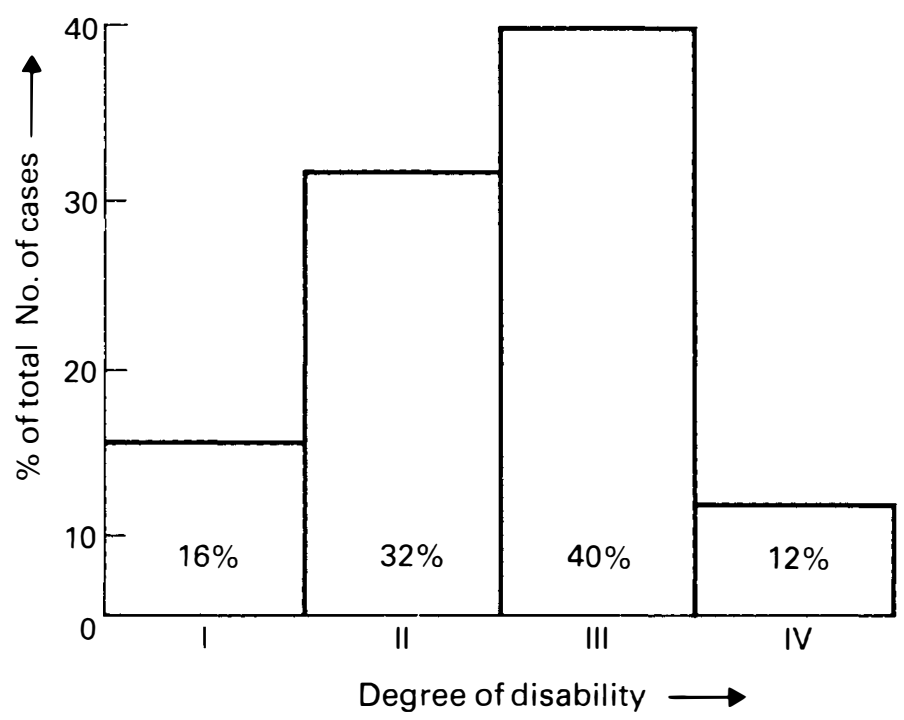

FIG. I

Showing total number of cases (75)-age distribution I3-63 years (6I male and I 4 female), plotted against grade of disability.

\section{Degree of Disability}

The degree of disability was classified according to the amount of function in the upper and lower limbs as shown in Table I. Note: All \% figures refer to the total number of 75 patients unless otherwise stated.

In our research schedule, facility was built in to allow us to classify upper limb function separately from lower limb function. In the 75 cases examined, however, patients with significantly impaired upper limb function also displayed severe lower limb function and were therefore classified as Group IV (Table I).

The distribution of the degree of disability is shown in Figure I. As can be seen, about 50 per cent of these patients constitute Groups III and IV which represents a very considerable degree of disability.

\section{Permanent Return Home After Rehabilitation}

When asked whether they felt that they were suitably prepared for discharge by the time they left the Spinal Injury Unit 85 per cent of patients felt that they 
TABLE I

\begin{tabular}{|c|c|c|}
\hline Code & Degree of disability & Level of function \\
\hline I & No/Mild disability & Able to walk normally \\
\hline II & Moderate disability & $\begin{array}{l}\text { Some limitation in walking } \\
\text { or uses walking aid }\end{array}$ \\
\hline III & Severe disability & $\begin{array}{l}\text { Relies on wheelchair most } \\
\text { or all of the time }\end{array}$ \\
\hline IV & Very severe disability & $\begin{array}{l}\text { As III with impaired upper } \\
\text { limb function }\end{array}$ \\
\hline
\end{tabular}

were. On the other hand, 24 per cent of people felt that the support available at the time of discharge was inadequate. Seventy per cent of patients were allocated a social worker by the local authority at the time of discharge. Twelve per cent were allocated an occupational therapist also. Eighty-eight per cent of patients had spent either week-ends or days at home prior to discharge. Patients were asked whether they considered that the service provided by the Spinal Injury Unit (SIU) was satisfactory or otherwise. Ninety-six per cent were satisfied with the service provided by the Unit.

\section{Housing}

The type of accommodation in use by each person was recorded (Table II). The conventional house remained the most frequently used type of accommodation throughout the range of disability, though a significant proportion of the very severely disabled lived in a bungalow. Regarding the location of housing and the provision of adaptations, I3 patients ( 17 per cent) felt that they had not been sufficiently consulted overall. Fifty-six per cent of patients had been able to return to their own home after discharge. About one third of these patients were owner-occupiers and two thirds were council tenants.

When adaptations were required to a property ( 28 per cent) the average time taken to complete the work was 3 months (i.e. from time of home visit by the Occupational Therapists to time of completion). In 12 cases, an extension was recommended, though this was actually only provided in eight cases. Access via

TABLE II

\begin{tabular}{|c|c|c|c|c|c|}
\hline \multirow[t]{2}{*}{ Housing } & \multicolumn{5}{|c|}{ Disability } \\
\hline & I & II & $\overline{\text { III }}$ & IV & Total \\
\hline House & $9(12 \%)$ & I8 $(24 \%)$ & I7 $(23 \%)$ & $5(7 \%)$ & $49(65 \%)$ \\
\hline Bungalow & I & $6(8 \%)$ & $7(9 \%)$ & $3(4 \%)$ & I7 $(23 \%)$ \\
\hline Flat-Downstairs & I & I & $3(4 \%)$ & I & $6(8 \%)$ \\
\hline Flat-Upstairs & 0 & I & 0 & 0 & I \\
\hline Hospital & I & o & I & 0 & 2 \\
\hline Total & I 2 & 26 & 28 & 9 & 75 \\
\hline
\end{tabular}


ramps, when necessary, was generally satisfactory. In nine cases ( 12 per cent) essential doors were of inadequate width.

\section{Facilities Within The Home}

Most homes were equipped with central heating (73 per cent) and a telephone (77 per cent). Everyone possessed a television. In the kitchen, adaptations were broadly satisfactory. In the bathroom also aids such as grab-rails, monkey-pole handles, non-slip mats, etc, were used regularly in a high percentage of cases and were considered satisfactory overall.

Lifts had been provided for ten patients ( 13 per cent). All those with lifts were satisfied with them and used them regularly. (See Table III-it is acknowledged that these figures are small for statistical purposes.)

Seventy per cent of these patients had been supplied with wheelchairs, 44 per cent had to wait longer than I month to be supplied with one. Four patients had to wait 6 months and two patients waited more than a year. A Possum unit had been supplied to 8 per cent of the patients; all patients valued this highly.

TABLE III

\begin{tabular}{ll}
\hline Type of lift & No. \\
\hline Electric-Vertical & 2 \\
Manual-Vertical & 5 \\
Electric-Stairlift & 3 \\
Total & Io $(13 \%)$ \\
\hline
\end{tabular}

\section{Mobility}

This is an important factor in successful rehabilitation because of its influence on employment prospects, social life and general independence. Seventh-six per cent of patients had access to a car and 44 per cent of people owned their own car. The great majority of people ( 72 per cent) received no help in buying a car. Four per cent of people used the motability scheme, which however did not start until I978). Twenty-four (69 per cent) of the 35 cars individually owned were adapted. There had been little difficulty in obtaining third party insurance cover, though 22 per cent of those applying for comprehensive cover had experienced difficulty in obtaining it.

Bearing in mind the degree of mobility conferred by cars, the wheelchairaccessibility of public buildings becomes increasingly important. Considerable difficulty was reported in this respect. Table IV lists the problems of access reported. The lower the facility appears in the list, the greater the difficulty in access.

\section{Health}

Since discharge, 50 per cent of patients have required at least one admission to hospital. (Reconstructive procedures, urinary complications, pressure sores, etc.) 


\section{TABLE IV}

Facility accessibility

Public park/gardens

Club

Shops

Launderette

Cinema

Public library

Post office

Bank

Bingo hall

Swimming pool

Sports facilities

Public house

N.B. Least accessible at bottom of table

\section{Pressure Sores}

Nine per cent of people had a pressure sore at the time of the interview. However, if one considered the incidence of sores from the time of injury, 25 people (33 per cent) had developed one or more sores during that time (i.e. $4 \frac{1}{2}$ years).

\section{Family Relationships}

The marital status before injury in terms of the whole group of people is described in Table V. The data shows that 52 per cent of this group of people were married at the time of injury. Since the time of the accident, the following changes in marital status have occurred. In 86 per cent of cases no change had been reported. Two patients had had children since injury; both were paraplegic (disability Grade 2), one a housewife of 33 years of age and the other a 25-year-old man.

\begin{tabular}{lcc}
\multicolumn{3}{c}{ TABLE V } \\
\hline $\begin{array}{c}\text { Marital } \\
\text { status }\end{array}$ & $\begin{array}{c}\text { Before } \\
\text { injury }\end{array}$ & $\begin{array}{c}\text { Since } \\
\text { injury }\end{array}$ \\
\hline $\begin{array}{c}\text { Single } \\
\text { Married }\end{array}$ & 30 & 28 \\
Divorced & 39 & 35 \\
Separated & I & 4 \\
Widowed & 3 & 5 \\
Total & 2 & 3 \\
\hline
\end{tabular}

\section{Sexual Relationships}

Fifty-four patients ( 72 per cent) had a sexual relationship before injury. Forty-eight of them ( 89 per cent) stated that this had changed or ceased since injury. Space precludes a more detailed review of this subject. Of those for whom 
sexual counselling was applicable, I 2 had received such help (I 8 per cent) but 46 (7I per cent) had not. Twenty-seven per cent of patients stated that they would welcome a more readily available sexual counselling service.

\section{Employment}

Patients of working age were visited by the Disablement Resettlement Officer (D.R.O.) in hospital (35 patients-47 per cent of the total). Sixteen people were retrained for work (Table VI). Thus 46 per cent of those eligible received some form of retraining. Seventy-seven per cent of the whole group had to abandon or alter their career plans. At the time of interview, I3 patients (I7 per cent) were employed-I I males and two females Ten of these employed people (77 per cent) drove themselves to work. The number of people at work diminished as disability increased (Table VI).

TABLE VI

\begin{tabular}{cc}
\hline $\begin{array}{c}\text { Disability } \\
\text { code }\end{array}$ & $\begin{array}{c}\text { No. of people } \\
\text { at work }\end{array}$ \\
\hline I & 7 \\
II & 5 \\
III & I \\
IV & 0 \\
Total & I3 \\
\hline
\end{tabular}

\section{Compensation}

Fourteen people had received compensation at the time of interview (I8.7 per cent). The average time that compensation had been achieved was 3 I months. A further six patients expected to receive compensation, making a total of 20 people with a reasonable expectation of compensation in the whole series (i.e. 27 per cent).

\section{Social Integration}

Forty-one per cent of people had lost contact with friends as the result of being handicapped, against this, however, 72 per cent of people had made new friends through their handicap. Most people (70 per cent) did not feel discriminated against because of their handicap. The most popular leisure activities in order of descending popularity are shown in Table VII.

\section{Conclusions}

As the result of this survey (of which this report is a brief summary) we are building into our rehabilitation programme additional elements, some of which are listed below.

I. Study days for relatives and patients in order to prepare them with useful knowledge for the future. 
TABLE VII

\begin{tabular}{lc}
\hline \multicolumn{1}{c}{ Leisure activities } & No. of patients \\
\hline Listening to music & 66 \\
Watching TV & 62 \\
Reading & 36 \\
Woodwork/mechanical & 32 \\
Animals & $3 \mathrm{I}$ \\
Home and garden & 28 \\
Participating in sport & 24 \\
Watching sport & 23 \\
Bingo/gambling & I 5 \\
Crafts & I 4 \\
Cinema/theatre & I4 \\
Playing music/singing & I3 \\
Photography & I 2 \\
Art & IO \\
Writing & 9 \\
Religious activity & 6 \\
\hline
\end{tabular}

2. Improved liaison with the Specialists in Community Medicine in our region in order to improve the quality of overall care immediately after discharge from the Unit.

3. We are investigating the possibility of developing a liaison with the Department of Architecture at Newcastle University in order that we may set up study days with the architectural students.

4. We have set up a small workshop system as part of the Occupational Therapy Unit. This is run by a Technical Instructor. Articles manufactured are sold in a shop which we have opened within the largest store in Hexham. (We have been greatly encouraged and assisted by the owner of the store and his staff.) It is hoped that this project will maintain the work 'ethic' and will encourage and assist patients to more seriously consider looking for a suitable job and to become more active in craft activities. We believe that the patients' quality of life will be enhanced by these means.

5. We have obtained a (non-mobile) car in order to ensure that all suitable patients are familiar with handling the controls and entry and exit.

6. We are making efforts (as are other groups) to make local authorities aware of the difficulties of wheelchair access to public buildings.

This paper has been of necessity a very brief review of our survey. Apart from revealing ways in which the rehabilitation programme could be improved, it has pointed out positive ways in which a Spinal Injury Unit can help patients once they have left the Unit and are living in the community again.

\section{SUMMARY}

The various aspects of the social circumstances of patients rehabilitated in the North of England Regional Spinal Injury Unit between 1975 and 1979 have been investigated. The study was carried out by making use of computerised analysis 
of a specially developed questionnaire. A Research Medical Social Worker was appointed to visit each patient at their home in order to record all relevant information into the questionnaire.

A summary of the resulting information is presented. The study has been of particular value in two respects. Firstly, it has revealed the comprehensive social circumstances of these patients. Secondly, it has enabled us to evaluate the quality of service provided by the Hexham Regional Spinal Injury Unit, and it has enabled us to recommend an expansion of some of the aspects of the service provided by a Spinal Injury Unit.

Acknowledgement. The authors would like to thank the Regional Research Committee of the Northern Regional Health Authority, Newcastle upon Tyne, for the grant which made this study possible. Our sincere thanks also to Mr A. McNay and his staff in the Statistical Department of the above-mentioned authority for their advice and help.

\section{RÉSUMÉ}

On a examiné les differents aspects des conditions sociales des patients qui ont été réhabilités entre 1975 et 1979 dans le service régional des blessures vertébrales dans l'Angleterre du nord. L'examen a été effectué au moyen d'une analyse d'ordinateur tirée d'un questionnaire specialement rédigé. Une assistante sociale s'occupant de recherches médicales a dû rendre visite chez chaque malade à domicile pour consigner par écrit dans le questionnaire tous renseignements utiles.

Vous trouverez c-joint un sommaire des informations qui en sont découlées. L'étude a été d'une valeur importante sous deux rapports. En premier lieu elle a révelé les conditions sociales d'ensemble qui vivent ces malades. En second lieu elle nous a permis d'évaluer la qualité des soins que fournit le Service Régional des blessures vertébrales à Hexham et elle nous a mis en état de recommander un development de quelques-uns des traitements offerts par un service de blessures vertébrales.

\section{ZUSAMMENFASSUNG}

Die verschiedenen Aspekte der sozialen Umstände von Patienten im Norden von England, die in der regionalen Abteilung für Wirbelsäulenverletzte in den Jahren von 1975 bis 1979 rehabilitiert wurden, sind untersucht worden. Die Untersuchung wurde mit Hilfe der Komputer analyse und eines, für diese Zwecke entwickelten, Fragebogens durchgeführt. Ein medizinischer Sozialfürgorger wirde für diese Untersuchung eingestellt, um jedem Patienten einen Hausbesuch abzustatten und alle wichtigen Informationen in den Fragebogen einzutragen.

Eine Zusammenfassung der Ergehnisse wird präsentiert. Die Untersuchungen waren aus zwei Gründen von Besonderem Wert. Erstens wurden die umfassenden sozialen Umstände dieser Patienten enthüllt. Zweitens ermöglichte es uns, die Qualität der Hilfe, die von der regionalen Abteilung für Wirbelsäulenverletzte gegeben wird, auszuwerten und eine Erweiterung dieser Hilfe in bestimmter Richtung zu empfehlen.

\section{REFERENCES}

Forner, J. V., Miro, R., Manteiga, A., Suares, S. \& Serra, M. (I976). Social and working conditions of our paraplegics. Paraplegia, 14, 74-78.

Hallin, R. P. (I968). Follow-up of paraplegics and tetraplegics after comprehensive rehabilitation. Paraplegia, 6, I28-I34.

JACkson, R. W. (1972). Survey of sexual rehabilitation after cord injury. Paraplegia, Io, 50-55.

Johnson, G. S., Johnson, R. H. \& Bowie, G. (1972). Problems of social integration for paraplegics in Scotland. Paraplegia, Io, I26-I33. 
RUNGE, M. (1966). Follow-up study of self care activities in traumatic spinal cord injury, quadriplegics, quadriparetics. Am. F. Occ. Ther., 20, 24I-249.

SpIEKER, J. L. \& LeTHCOE, B. J. (I97I). Upper extremity bracing-a follow-up study. Am. F. Occ. Ther., 15, 398-40 I.

Wilcox \& STAUfFer. (I972). Follow-up of 423 consecutive patients admitted to the Spinal Cord Centre, Rancho Los Amigos Hospital. Jan. I-Dec. 31, 1967. Paraplegia, I0, I I 5-I 72 . 